Mеталлофиз. новейшие технол. / Metallofiz. Noveishie Tekhnol. () 2017 ИМФ (Институт металлофизики 2017 , т. 39 , № 10, сc. 1363-1375 / DOI: $10.15407 /$ mfint.39.10.1363 им. Г. В. Курдюмова НАН Украины) Оттиски доступны непосредственно от издателя

Фотокопирование разрешено только

Напечатано в Украине.

в соответствии с лицензией

PACS numbers: 61.43.Gt, 62.20.D-, 81.05.Rm, 81.40.Jj, 81.40.Lm, 81.70.Bt, 83.80.Iz

\title{
Mechanical Behaviour of the Porous and Foam Aluminium in Conditions of Compression: Determination of Key Mechanical Characteristics
}

\author{
O. V. Byakova, A. O. Vlasov, M. V. Semenov, O. V. Zatsarna*, \\ and S. V. Gnyloskurenko**
}

\author{
I. M. Frantsevich Institute for Problems in Materials Science, N.A.S. of Ukraine, \\ 3 Academician Krzhyzhanovsky Str., \\ UA-03142 Kyiv, Ukraine \\ "G.V. Kurdyumov Institute for Metal Physics, N.A.S. of Ukraine, \\ 36 Academician Vernadsky Blvd., \\ UA-03142 Kyiv, Ukraine \\ **Physico-Technological Institute of Metals and Alloys, N.A.S. of Ukraine, \\ 34/1 Academician Vernadsky Blvd., \\ UA-03142 Kyiv, Ukraine
}

The paper emphasizes harmonized recommendations for mechanical tests of highly-porous aluminium and aluminium foam to be applicable for analysing their compression response under quasi-static loading as well as determining reliable and reproducible results essentially required for practice problems of engineering design. Key mechanical parameters are designated and specified by considering distinctive features of deformation patterns indicative of porous aluminium and aluminium foam with a cellular structure. Special attention is paid to the problem related to inhomogeneous deformation of the above-mentioned materials, resulting in variation of quasi-elastic structural stiffness as well as shape and length of plateau regime of the stress-strain curve. Application of the harmonized recommendations is demonstrated with using several kinds of foam aluminium fabricated in line with different processing route. Using the above recommendation, significant effect of processing additives on micromechanism of deformation and, in turn, on macro-

Corresponding author: Oleksandra Viktorivna Zatsarna

E-mail: alexsandra.ku@gmail.com

Please cite this article as: O. V. Byakova, A. O. Vlasov, M. V. Semenov, O. V. Zatsarna, and S. V. Gnyloskurenko, Mechanical Behaviour of the Porous and Foam Aluminium in Conditions of Compression: Determination of Key Mechanical Characteristics, Metallofiz. Noveishie Tekhnol., 39, No. 10: 1363-1375 (2017), DOI: $10.15407 /$ mfint.39.10.1363. 
scopic compressive response of $\mathrm{Al}$ foams resulted from contamination of the cell wall material by side products is shown and clarified.

Key words: porous metals, metallic foams, compression test, quasi-static loading.

В роботі висвітлено новітні унормовані рекомендації стосовно механічних випробувань високопоруватого та спіненого алюмінію, які є придатними для аналізу механічної поведінки цих матеріялів в умовах стиснення та отримання надійних та відтворюваних результатів, істотно необхідних для вирішення задач інженерної практики. 3 урахуванням особливостей деформаційних кривих, притаманних комірчастій структурі високопоруватого та спіненого алюмінію, надано відомості щодо визначення їхніх ключових механічних характеристик. Особливу увагу приділено неоднорідному характеру деформації зазначених матеріялів, що спричиняє зміни у структурній цупкості, а також формі та довжині ділянки плато на кривій «напруження-деформація». Застосування унормованих рекомендацій було продемонстровано із застосуванням декількох видів спіненого алюмінію, виготовленого за різними технологічними процедурами. 3 урахуванням висвітлених рекомендацій зареєстровано істотний вплив технологічних додатків на мікромеханізм деформації та, як наслідок, на механічну поведінку спіненого алюмінію в цілому, що пояснюється забрудненням матеріялу стінок між комірками сторонніми продуктами реакцій.

Ключові слова: пористі метали, металеві піни, випробування на стиск, квазистатичне навантаження.

В работе приведены современные рекомендации для механических испытаний высокопористого и вспененного алюминия, которые пригодны для анализа механического поведения этих материалов в условиях сжатия и получения надёжных и воспроизводимых результатов, необходимых для решения задач инженерной практики. С учётом особенностей деформационных кривых, присущих ячеистой структуре высокопористого и вспененного алюминия, представлены сведения относительно определения их ключевых механических характеристик. Особое внимание уделено неоднородному характеру деформации указанных материалов, что вызывает изменения в структурной жёсткости, а также форме и длине участка плато на кривой «напряжение-деформация». Применение разработанных рекомендаций было продемонстрировано с использованием нескольких видов вспененного алюминия, изготовленного по различным технологическим процедурам. Разработанные рекомендации позволили зарегистрировать существенное влияние технологических добавок на микромеханизм деформации и, как следствие, на механическое поведение вспененного алюминия в целом, что объясняется загрязнением материала стенок между ячейками побочными продуктами реакций.

Ключевые слова: пористые металлы, металлические пены, испытание на сжатие, квазистатическая нагрузка.

(Received July 23, 2017) 


\section{INTRODUCTION}

Highly-porous aluminium and aluminium foams are a group of a new, as yet unfamiliar to the most engineers, class of materials with cellular structure and unique combination of low density and novel physical, mechanical, thermal, electrical, and acoustic properties [1, 2]. In particular, they have stiffness/mass ratio which superiors by several times to that of dense aluminium alloys commercially available today. Moreover, highly-porous $\mathrm{Al}$ and $\mathrm{Al}$ foams show exclusive capacity to undergo large strains (up to $60-70 \%$ ) at an almost constant stress in compression, providing their remarkable ability to absorb mechanical energy and making them attractive for different engineering applications where effective utilization of impact energy is required and, particularly, for those in transport industry [1-3]. Because of this, there has been extensive interest in development of production and mechanical performance of $\mathrm{Al}$ foams and highly porous $\mathrm{Al}$ [1, 2, 5-14]. However, despite of promising structural and functional properties of the above materials, their penetration in market by application in engineering practice is yet strongly limited. Besides technical and economical limitations, lack of guidelines addressed to engineering design and, particularly, those related to designation of mechanical performance metrics for the above materials impedes their transfer in engineering practice. However, the deformation behaviour of cellular metals including porous $\mathrm{Al}$ and $\mathrm{Al}$ foams is quite different from conventional dense materials and dependent on volume fraction of solid, i.e. relative density $\rho / \rho_{s}$ (where $\rho$ is density of cellular structure and $\rho_{s}$ is density of the solid). Because of this, test method procedures addressed to determining the set of mechanical parameters for conventional metallic materials are not appropriate for porous $\mathrm{Al}$ and $\mathrm{Al}$ foams. Whereupon, theoretical models $[1,3,9,10]$ based on an idealized representation of cellular structure were found to be inadequate to represent the actual profile of mechanical properties for real porous metals and metallic foams [9, 10]. Different imperfections existing in real $\mathrm{Al}$ foams, processing additives, and variation in the testing conditions result in considerable disagreements between experimental results and theoretical predictions [10, 15-22]. Thus, specification of mechanical tests for porous $\mathrm{Al}$ and $\mathrm{Al}$ foams with well-defined data related to microstructure of the cell wall material is a way to provide for validity of material verification essential for engineering design. Guidelines for test method procedure suitable for porous $\mathrm{Al}$ and $\mathrm{Al}$ foams are originated from distinctive features of their compressive response. Figure 1 shows schematically distinctive features of compressive response of highly porous $\mathrm{Al}$ and $\mathrm{Al}$ foam with relative density $\rho / \rho_{s}<\mathbf{0 . 5}$.

Linear elastic regime I before general yielding is followed by well- 
defined plateau regime II that continues up to large strains beyond which the stress increases sharply within densification regime III. It was specified that linear elastic response be related to cell edge bending in open-cell material while the edge bending combined with face stretching is typical for closed-cell foam $[3,9]$.

As the stress increases, the cells begin to collapse in response to roughly constant stress by elastic buckling, yielding or fracture, depending on the nature of the cell wall material [3, 9]. As shown in Fig. 1 , plateau stress is smooth for elastic-plastic material while numerous hardening/softening sequences are visible in plateau stress when localized crushing of deformation bands contributes in geometrical cell collapse. In the case of closed-cell foam, tensile membrane being originated under the pressure of entrapped gas leads to stretching of cell faces and, as consequence, causes the stress to rise up gradually up to densification [1]. Once all of the cells have collapsed, further deformation causes opposing cell walls to touch each other, originating sharp increasing the stress. Finally, material commences to densify completely. Of importance is the fact that open-cell material is strain rate insensitive while rate sensitive response may be expected for closed-cell $\mathrm{Al}$ foam, for which elastic-plastic is typical and, hence, micro-inertia effect dominates [23-25]. The latter effect results in the increase of plateau stress when strain rate increases essentially. The next characteristic feature concerns the initial responses of highly porous $\mathrm{Al}$ and $\mathrm{Al}$ foams, as can be seen in Fig. 2.

The slopes of the loading and unloading curves for elastic-plastic deformation are not identical. The slope of the loading curve is much lesser than that of unloading curve, indicating that local plastic deformation within the cell walls even at low strains and reducing the loading modulus below the unloading modulus. Because of this deter-

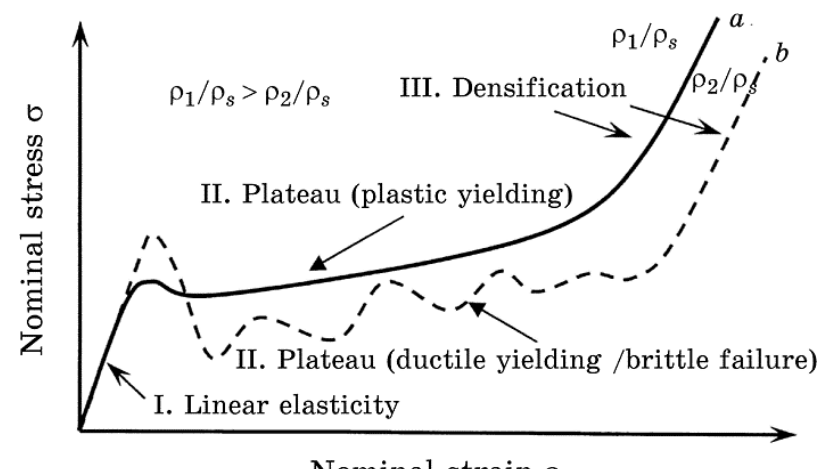

Nominal strain $\varepsilon$

Fig. 1. Schematic presentation of compression stress-strain curves for porous $\mathrm{Al}$ and $\mathrm{Al}$ foam showing the linear elastic, plateau and densification regimes: plastic cell collapse $(a)$, cell collapse partially affected by fracture mode $(b)$. 
mining the stiffness $m$ of porous $\mathrm{Al}$ and $\mathrm{Al}$ foams is realized with precautions shown schematically in Fig. 2 to overcome the risk of strong scatter of the data, ensuring the reproducibility of results.

The intent of the present paper is to clarify the distinctive features of test method procedure applicable for porous $\mathrm{Al}$ and $\mathrm{Al}$ foams, which is based on Standard ISO 13314: 2011 newly developed for compression test for porous and cellular metals.

\section{COMPRESSION TESTING OF POROUS ALUMINIUM AND ALUMINIUM FOAMS}

Harmonized conditions for compression tests are primary applicable for materials having cellular structure and relative density less than $\rho / \rho_{s}=0.5$ [26]. Compression tests are carried out by using universal servo hydraulic testing machines under displacement control and strain rates varied from $1 \cdot 10^{-3}$ to $1.3 \cdot 10^{-1} \mathrm{~s}^{-1}$. The specimens are placed between two lubricated (e.g., by graphite) and parallel steel plates of the hardness not less than $60 \mathrm{HRC}$. The dimensions of specimen with no skin have to be chosen in such a way that the each spatial direction should contain at least ten cells to avoid size effect. Specimens of cylindrical or rectangular shape and the ratio of length to diameter/edge between 1.5 and 2.0 are used to establish plane-strain conditions. Recommended dimensions of samples are $50 \mathrm{~mm}$ in diameter/edge and length of $100 \mathrm{~mm}$. Number of tested specimens should be not less than three although five ones are more acceptable. One additional specimen is required for a pre-test. Pre-test at strain rate of $\dot{e}=10^{-2} \mathrm{~s}^{-1}$ is implemented prior final testing to estimate the rough level of plateau stress $\sigma_{p l}$. In the final test, the sample is pre-loaded up to $0.02 \sigma_{p l}$ at the

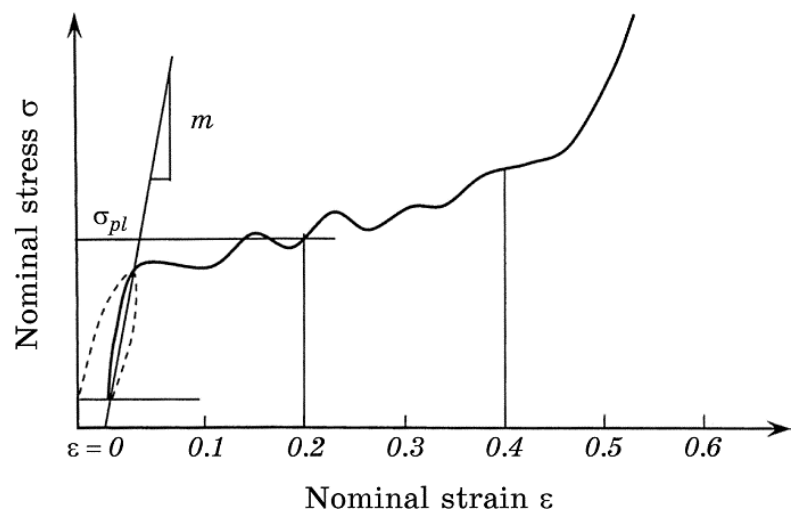

Fig. 2. Schematic presentation of determining the structural stiffness $m$ from initial region of stress-strain curve recorded in compression of porous $\mathrm{Al}$ and $\mathrm{Al}$ foams. 
strain rate $\dot{e}=10^{-3} \mathrm{~s}^{-1}$. Then, the sample is subjected to the loading to roughly about $0.7 \sigma_{p l}$ when nominal strain $\varepsilon$ remains less than $\cong 0.01$. Prior continuation of compression, the specimen is unloaded to $0.2 \sigma_{p l}$ and, then, reloaded to identify Young's modulus as a quasi-elastic structural stiffness $m$ being determined by the slope of secant line in hysteresis loop and shown by dashed line in Fig. 2. In addition, zero point for compression strain is defined by the intersection of quasielastic secant with abscissa, as shown in Fig. 2. Compression at the strain rate of $\dot{e}=10^{-3} \mathrm{~s}^{-1}$ is used until the strain reaches the value $\varepsilon=$ $=0.2$. Further compression test can be fulfilled either at the same or at the higher strain rates, i.e., from $\dot{e}=10^{-3} \mathrm{~s}^{-1}$ to $\dot{e}=10^{-1} \mathrm{~s}^{-1}$. The test can be terminated when compressive stress exceeds the value about $\sigma \cong$ $\cong 1.3 \sigma_{p l}$ suggesting global densification of structure.

Besides quasi-elastic structural stiffness $m$, offset yield strength $\sigma_{y}$, and plateau strength $\sigma_{p l}$ are the most important characteristics as to design purposes. Yield strength $\sigma_{y}$ is found at the onset of yielding and defined as the stress usually corresponding to nominal strain about $\varepsilon=$ $=0.01$, as shown in Fig. 3. Upper yield strength $\sigma_{u}^{u p}$ can additionally be measured when pronounced peak stress arises at the onset of global collapse. In this case, ratio $\sigma_{y}^{u p} / \sigma_{y}$ may be used as a measure of ductility for cellular structure. Plateau strength $\sigma_{p l}$ is defined in slightly different ways. Generally, the above strength characteristic is ascribed to the plateau stress either at the strain of $\varepsilon=0.2$ or that of $\varepsilon=0.4$. In addition, plateau strength reached just at the densification regime is also important. For this purpose, densification strain $\varepsilon_{D}$ has to be defined as the first step. The latter corresponds to crossing the tangent to deformation plateau and that to onset of densification, as shown in Fig. 3. In any way, nominal strain $\varepsilon$ at which plateau stress was determined has

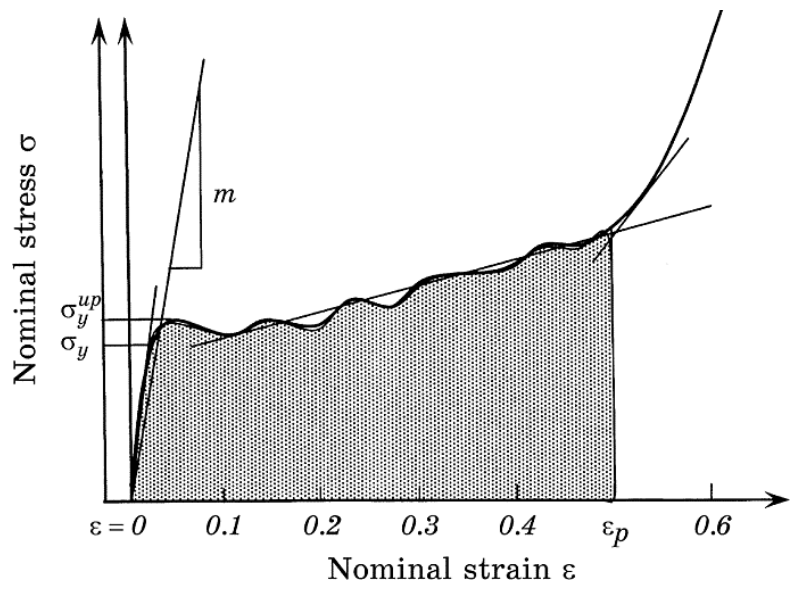

Fig. 3. Schematic presentation of determining key mechanical parameters from stress-strain curve recorded in compression of porous $\mathrm{Al}$ and $\mathrm{Al}$ foams. 
to be pointed out in the test report.

Area below plateau regime limited to densification strain $\varepsilon_{d}$ specify capability of cellular material to absorb mechanical energy $E$, as shown in Fig. 3. In addition, energy absorption at nominal strains such as $\varepsilon=0.2$ and $\varepsilon=0.4$ can be identified when it is necessary.

\section{EXPERIMENTAL EVALUATION OF COMPRESSIVE RESPONSE FOR ALUMINIUM FOAMS}

\subsection{Materials and Processing}

As an example, capability approval of harmonized test method procedure listed above (see Section 2) for analysis compressing response were done by using different kinds of closed-cell $\mathrm{Al}$ foams denoted here as $F_{1}, F_{2}, F_{3}, F_{4}$, as listed in Table 1 . Relatively ductile $\mathrm{Al}-\mathrm{Si}-\mathrm{Mg}$-alloy with composition $\mathrm{Al}-1 \mathrm{Mg}-0.6 \mathrm{Si}-0.28 \mathrm{Cu}-0.2 \mathrm{Cr}$ (similar to 6061 ) and $\mathrm{Al}-\mathrm{Zn}-\mathrm{Mg}$-alloy with composition $\mathrm{Al}-5.5 \mathrm{Zn}-3 \mathrm{Mg}-0.6 \mathrm{Cu}-0.5 \mathrm{Mn}$ (similar to 7075 alloy) doped additionally by small amount $(<0.6 \%$ mass) of Sc and $\mathrm{Zr}$ were used as parent alloys in experiments.

As shown in Fig. 4, $a$, microstructure of AlSiMg-alloy consist of coarse $\alpha$-Al dendrites rounded by thin network of the eutectic domains.

The results of elementary distribution combined with evidences of appropriate phase diagrams testify that composition of eutectic domains of $\mathrm{Al}-\mathrm{Si}-\mathrm{Mg}$-alloy are found to be compositionally corresponded to either $E\left(\alpha-\mathrm{Al}+\mathrm{Mg}_{2} \mathrm{Si}\right)(1)$ or $E\left\{\alpha-\mathrm{Al}+\mathrm{S}\left(\mathrm{Al}_{2} \mathrm{CuMg}\right)\right\}$ (2) that includes a few zones of $E\left(\alpha-\mathrm{Al}+\mathrm{CuAl}_{2}\right)(3)$.

Dendrites of $\alpha-\mathrm{Al}$ are rounded by interdendritic network of brittle $E$ $\{\alpha-\mathrm{Al}+\mathrm{T}(\mathrm{AlCuMgZn})\}$ redundant phase (4) together with randomly scattered primary crystals of $\mathrm{Al}_{3}(\mathrm{ScZr})$ intermetallic compound (5) are

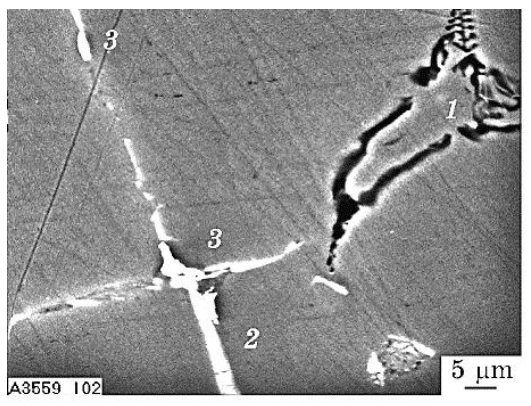

$a$

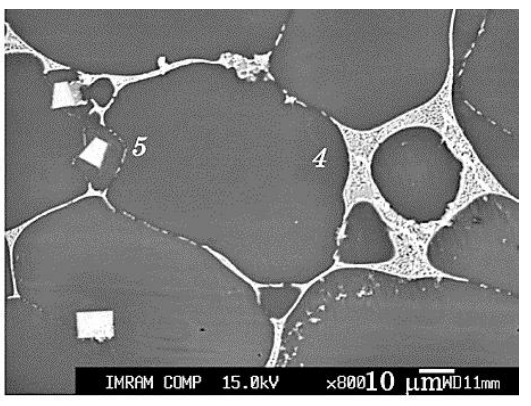

b

Fig. 4. SEM micrographs for microstructure of parent alloys $\mathrm{Al}-\mathrm{Mg}-0.6 \mathrm{Si}$ alloy $(a)$ and $\mathrm{Al}-\mathrm{Zn}-\mathrm{Mg}$-alloy $(b): E\left(\alpha-\mathrm{Al}+\mathrm{Mg}_{2} \mathrm{Si}\right)(1), E\left\{\alpha-\mathrm{Al}+\mathrm{S}\left(\mathrm{Al}_{2} \mathrm{CuMg}\right)\right\}$ (2), $E\left(\alpha-\mathrm{Al}+\mathrm{CuAl}_{2}\right)(3), E\left\{\alpha-\mathrm{Al}+\left[\mathrm{T}\left(\mathrm{Mg}_{3} \mathrm{Zn}_{3} \mathrm{Al}_{2}\right)+\mathrm{T}\left(\mathrm{CuMg}_{4} \mathrm{Al}_{6}\right)\right]\right\}(4)$, $\mathrm{Al}_{3}(\mathrm{ScZr})$ crystals (5). 
TABLE 1. Characteristics for different kind of $\mathrm{Al}$ foams and cell wall solid materials.

\begin{tabular}{c|c|c|c|c}
\hline Code & Parent alloy & $\begin{array}{c}\text { Processing } \\
\text { additives, \% wt. }\end{array}$ & $\begin{array}{c}\text { Relative density, } \\
\left(p / p_{s}\right)^{2)}\end{array}$ & $\begin{array}{c}\text { Solid yield } \\
\text { strength } \sigma_{y s}, \mathrm{MPa}\end{array}$ \\
\hline$F_{1}$ & 6061 & $1.5 \cdot \mathrm{TiH}_{2}+1 \cdot \mathrm{Ca}$ & 0.26 & $124 \pm 11.2$ \\
$F_{2}$ & 6061 & $2 \cdot \mathrm{CaCO}_{3}$ & 0.28 & $178 \pm 10.0$ \\
$F_{3}$ & $7075^{1)}$ & $2 \cdot \mathrm{CaCO}_{3}+1 \cdot \mathrm{Ca}$ & 0.26 & $213 \pm 9.5$ \\
$F_{4}$ & $7075^{1)}$ & $2 \cdot \mathrm{CaCO}_{3}$ & 0.28 & $260 \pm 13.0$ \\
\hline
\end{tabular}

Note: ${ }^{1)}$ alloy was additionally doped by small amount of Sc and $\mathrm{Zr}$ (totally of $0.6 \%$ wt.), ${ }^{2} p$ and $p_{s}$ correspond to the density of foam and dense solid, respectively.

found in microstructure of AlZnMg-alloy, as shown in Fig. 4, $b$. In addition, pronounced segregation of alloyed elements is visible within eutectic domains since $\mathrm{T}(\mathrm{AlCuMgZn})$ phase is a mixture of two different phase, i.e. $\mathrm{T}\left(\mathrm{Mg}_{3} \mathrm{Zn}_{3} \mathrm{Al}_{2}\right)$ and $\mathrm{T}\left(\mathrm{CuMg}_{4} \mathrm{Al}_{6}\right)$. It is a fact of great importance that fraction volume of eutectic domains contained by $\mathrm{Al}-$ $\mathrm{Zn}-\mathrm{Mg}$-alloy much superior to that presented in $\mathrm{Al}-\mathrm{Si}-\mathrm{Mg}$-alloy .

All kinds of $\mathrm{Al}$ foams were fabricated in line with melt processing like Alporas route, in which either titanium hydride $\mathrm{TiH}_{2}\left(F_{1}\right)$ or calcium carbonate $\mathrm{CaCO}_{3}\left(F_{2}-F_{4}\right)$ were employed as foaming agents and produced either with or without $\mathrm{Ca}$ additive introduced into melt as thickening agent, as evidenced from Table 1 . In addition, the Cabearing $\mathrm{Al}$ foams $\left(F_{1}, F_{3}\right)$ were fabricated according to procedure described in details in [12-14] while the $\mathrm{Al}$ foams $\left(F_{2}, F_{4}\right)$ were produced using modified processing route [8].

\subsection{Compressive Testing}

Several prismatic specimens with dimensions $20 \times 20 \times 30 \mathrm{~mm}^{3}$ and comparable relative density $p / p_{s}$ were machined from large foamed blocks. All the foamed samples were compressed in line with newly developed recommendations, which are presented in subscription 2 . In addition, several samples of the same dimensions and compositions roughly corresponded to the cell wall materials, which are formed in the studied $\mathrm{Al}$ foams, were fabricated by casting and then subjected to compression to determine their yield strength $\sigma_{y s}$ listed in Table 1. Quasi-static tests of the samples were performed under uniaxial compression by using Instron testing machine.

\subsection{Results and Discussion}

Figure 5 shows compressive stress-strain curves for the different 
kinds of $\mathrm{Al}$ foams with roughly comparable relative density. As an example, determination of the structural stiffness $m$ and zero point for compression strain of the $\mathrm{Al}$ foam $F_{2}$ are also shown in insertion of Fig. 5 .

It can be seen that $\mathrm{Al}$ foams exhibit rather different quasi-elastic structural stiffness $m$ and shape of deformation patterns. The slope of the stress-strain curve before yield for the $\mathrm{Al}$ foam $F_{1}$ is greater than that for the other kinds of the $\mathrm{Al}$ foams $\left(F_{2}, F_{3}\right.$, and $\left.F_{4}\right)$, which demonstrate rather similar elasticity stiffness. Pronounced differences among deformation patterns for different kinds of $\mathrm{Al}$ foams are revealed under plateau regime. Smooth plateau stress is observed for the Al foam $F_{1}$ while inhomogeneous microscopic deformation is typical for the $\mathrm{Al}$ foams $F_{2}, F_{3}, F_{4}$. Beyond the yield, the $\mathrm{Al}$ foams $F_{2}, F_{3}, F_{4}$ display peak stress that is followed by a load softening to plateau regime.

In addition, pronounced oscillations superimposed upon increasing plateau stress level with increasing strain are found to be typical for the $\mathrm{Al}$ foams $F_{3}, F_{4}$ while only a few very small hardening/softening sequences are visible in deformation pattern of the $\mathrm{Al}$ foam $F_{2}$.

The above deformation events are commonly ascribed to brittle fail-

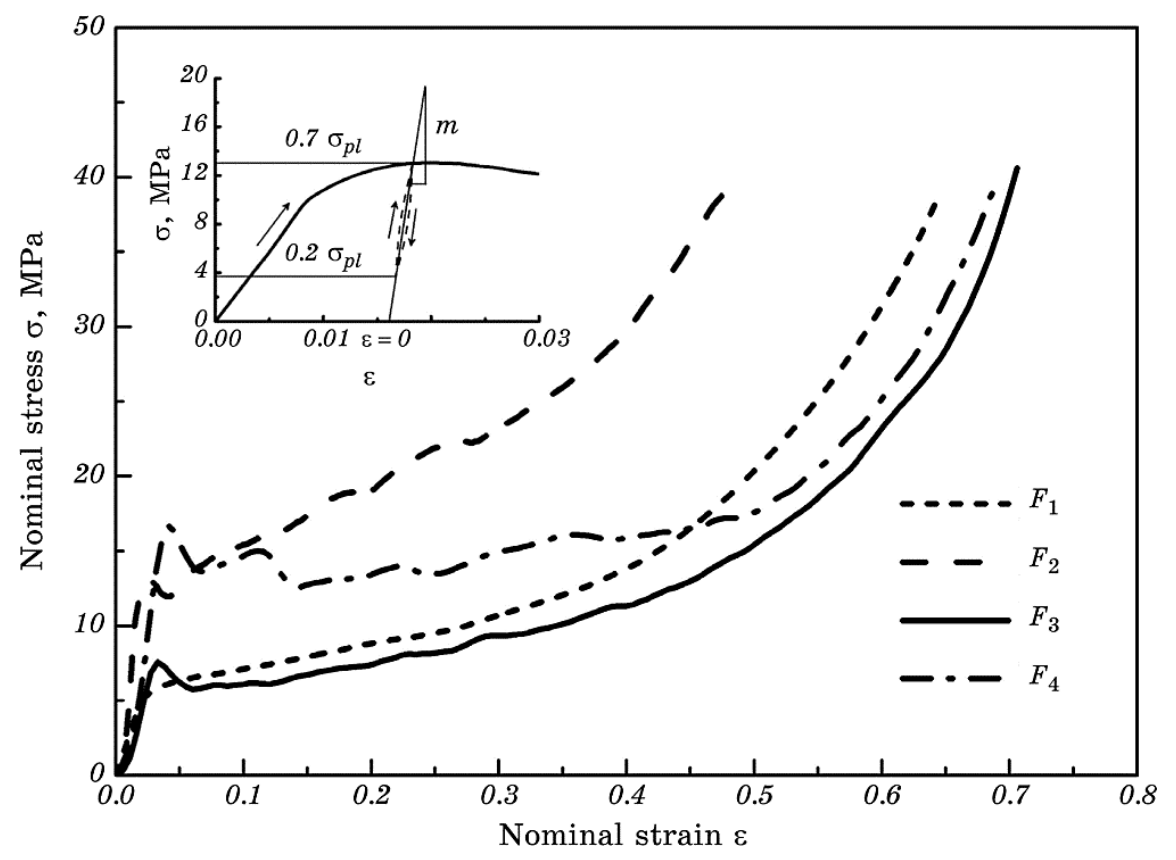

Fig. 5. Stress-strain curves for different kinds of $\mathrm{Al}$ foams with roughly comparable relative density. Determination of the structural stiffness $m$ and zero point for compression strain of the $\mathrm{Al}$ foam $F_{2}$ is shown as example at the upper left-hand corner. 
ure of the cell walls resulted from the presence of brittle constituents, which contribute in the cell geometrical collapse [11-14]. In addition, hardening rate for different kinds of $\mathrm{Al}$ foams is rather different and dependent on contribution of brittle failure mode. Actually, hardening rate for the $\mathrm{Al}$ foam $F_{2}$ processed with relatively ductile $\mathrm{Al}-\mathrm{Si}-\mathrm{Mg}$ alloy much superior to that of the other kinds of $\mathrm{Al}$ foams. Contribution of brittle failure mode in geometrical collapse is the most pronounced for the $\mathrm{Al}$ foam $F_{4}$ whose cell wall material comprises brittle eutectic domains. Attention is paid to substantial strength degradation of the Ca-bearing $\mathrm{Al}$ foams $F_{1}, F_{3}$ compared to the $\mathrm{Al}$ foams $F_{2}, F_{4}$ processed with the same parent alloys but without $\mathrm{Ca}$ additive. Actually, addition of $\mathrm{Ca}$ in the melt leads to substantial softening of dense $\mathrm{Al}$ alloys, as evidenced from Table 1. Pronounced difference in structure of the cell wall material resulted from addition of Ca was originally shown in [14]. Figure 6 shows microstructure of the cell wall material for the $\mathrm{Al}$ foams $F_{1}, F_{3}$ processed with $\mathrm{Ca}$ additive.

The results of elementary distribution specified rearrangement of alloyed elements, resulting in formation of foreign Ca-bearing eutectic zones/particles. Besides $E\left(\alpha-\mathrm{Al}+\mathrm{Mg}_{2} \mathrm{Si}\right)$ eutectic domains indicative of parent $\mathrm{Al}-\mathrm{Mg}-\mathrm{Si}$ alloy, foreign eutectic zones such as $E(\alpha-\mathrm{Al}+$ $\left.+\mathrm{Al}_{4} \mathrm{Ca}\right)(6), E\left(\alpha-\mathrm{Al}+\mathrm{Al}_{4} \mathrm{CaCu}\right)(7)$ and crystals/particles of $\mathrm{Al}_{2} \mathrm{CaSi}_{2}$ are formed in the $\mathrm{Al}$ foam $\left(F_{1}\right)$, as shown in Fig. $6, a$. In addition, particle of partly decomposed $\mathrm{TiH}_{2}$ rounded by $\mathrm{Al}_{2} \mathrm{Ti} / \mathrm{Al}_{3} \mathrm{~T}$ layer are also presented in the microstructure of the $\mathrm{Al}$ foam $\left(F_{1}\right)$ processed with titanium hydride. The most sizable disturbance of material microstructure induced by $\mathrm{Ca}$ additive is found in $\mathrm{Al}-\mathrm{Zn}-\mathrm{Mg}$-alloy, as can be seen in Fig. 6, b. Dissolved $\mathrm{Ca}$ is largely accumulated within the eutectic domains of redundant phase, stimulating outflow of $\mathrm{Mg}$ into $\mathrm{Al}$ ma-

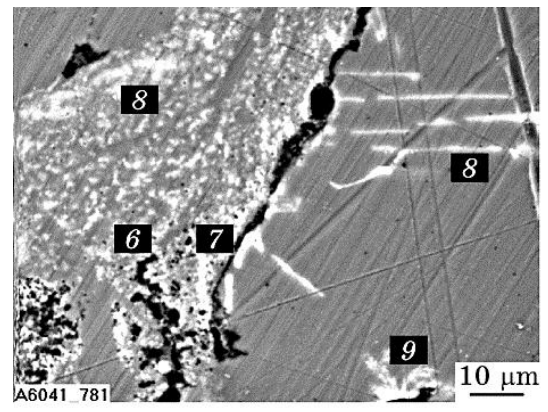

$a$

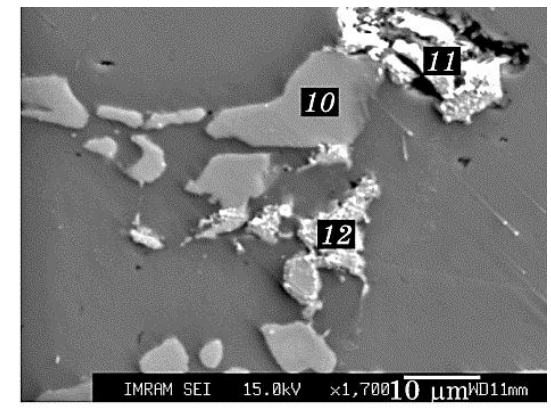

$b$

Fig. 6. SEM micrographs of the cell wall materials for the $\mathrm{Al}$ foams $F_{1}(a)$ and $F_{3}(b)$ both processed with $\mathrm{Ca}$ additive. In $(a), E\left(\alpha-\mathrm{Al}+\mathrm{Al}_{4} \mathrm{Ca}\right)(6), E(\alpha-\mathrm{Al}+$ $+\mathrm{Al}_{4} \mathrm{CaCu}$ ) (7), crystals/particles of $\mathrm{Al}_{2} \mathrm{CaSi}_{2}$ (8), particle of partly decomposed $\mathrm{TiH}_{2}$ rounded by $\mathrm{Al}_{2} \mathrm{Ti} / \mathrm{Al}_{3} \mathrm{~T}$ layer (9); in (b), $E\left\{\alpha-\mathrm{Al}+\mathrm{T}\left(\mathrm{Al}_{2} \mathrm{CaZn}_{2}\right)\right\}(10)$, $E\left\{\alpha-\mathrm{Al}+\mathrm{T}\left(\mathrm{Al}_{4} \mathrm{CaCu}\right)\right\}(11), E\left\{\alpha-\mathrm{Al}+\left\{\mathrm{T}\left(\mathrm{Al}_{2} \mathrm{CaZn}_{2}\right)+\mathrm{T}\left(\mathrm{Al}_{4} \mathrm{CaCu}\right)\right\}(12)\right.$. 
TABLE 2. Key mechanical parameters for different kinds of Al foams.

\begin{tabular}{|c|c|c|c|c|c|c|c|c|c|}
\hline \multirow[b]{2}{*}{ Code } & \multicolumn{8}{|c|}{ Experimental results } & \multirow{2}{*}{$\begin{array}{l}\text { Theoretical } \\
\text { predictions } \\
{ }^{55} \sigma_{p l} / \sigma_{y s}\end{array}$} \\
\hline & $\begin{array}{c}m, \\
\mathrm{GPa}\end{array}$ & $\sigma_{y} / \sigma_{y s}$ & $\left|\sigma_{y}^{u p} / \sigma_{y}\right|$ & $\varepsilon_{\mathrm{d}}$ & $\sigma_{p l}{ }^{1)} / \sigma_{y s}$ & $\left.\sigma_{p l}{ }^{2}\right) / \sigma_{y s}$ & $\sigma_{p l}^{3)} / \sigma_{y s}$ & $\begin{array}{c}E^{4)}, \\
\mathrm{MJ} / \mathrm{m}^{3}\end{array}$ & \\
\hline$F_{1}$ & 3.750 & 0.04 & - & 0.3 & 0.07 & - & 0.08 & 2.2 & 0.15 \\
\hline$F_{2}$ & 5.960 & 0.07 & 1.08 & 0.38 & 0.11 & - & 0.15 & 7.0 & \\
\hline$F_{3}$ & 4.615 & 0.03 & 1.10 & 0.42 & 0.04 & 0.05 & 0.06 & 3.2 & 0.15 \\
\hline$F_{4}$ & 5.660 & 0.06 & 1.16 & 0.5 & 0.05 & 0.06 & 0.07 & 7.2 & 0.17 \\
\hline
\end{tabular}

Note: $m$-quasi-elastic structural stiffness, $\sigma_{y}$-offset yield stress, $\sigma_{y}^{u p}$-peak stress, $\sigma_{p l}$-plateau stress at the prescribed strains such as ${ }^{1)} \varepsilon=0.2,{ }^{2)} \varepsilon=0.4,{ }^{3)} \varepsilon=\varepsilon_{d}, \varepsilon_{d}$ densification strain, ${ }^{4)}$ energy absorption up to densification, ${ }^{5)}$ calculated over theoretical relations [9] the same as it was fulfilled previously [13, 14].

trix. As a result Ca-bearing intermetallic compounds such as $\mathrm{Al}_{2} \mathrm{CaZn}_{2}$ (10) and $\mathrm{Al}_{4} \mathrm{CaCu}(11)$ are formed in eutectic domains since they are the most expected products appointed by corresponding phase diagrams. It is noticeable that despite of softening effect the above Ca-bearing compounds remain quite brittle for crack initiations, as was shown in [14].

The above structural characteristic features affect compressive response of $\mathrm{Al}$ foams, which give different values of key mechanical parameters listed in Table 2. Standard deviation in structural stiffness $m$ associated with Young's modulus varied between $5 \%$ and $25 \%$ of the mean, while deviations in the compressive stresses $\sigma_{y}$ and $\sigma_{p l}$ were found to be typically between $5 \%$ and $15 \%$, respectively.

Several aspects are reasonable to be mention here. Quasi-elastic structural stiffness $m$ increases as relative density $p / p_{s}$ increases. Micromechanism of deformation dominates considerably all the other strength properties although variation of relative density $p / p_{s}$ has much smaller effect. Increased ratio $\sigma_{y}^{u p} / \sigma_{y}$ as a measure of ductility for cellular structure suggests contribution of brittle failure mode in cell geometrical collapse. The latter increased as the value of ratio $\sigma_{y}^{u p} / \sigma_{y}$ increases. It is noticeable that increased contribution of brittle failure mode provides for increasing the strain that $\mathrm{Al}$ foams can undergo up to densification, resulting in enhancement of energy absorption under plateau regime. Attention is paid to discrepancy of the actual compressive strength for $\mathrm{Al}$ foams and theoretical predictions, making necessity of compression testing of strong importance to achieve reliability of engineering design.

\section{CONCLUDING REMARKS}

Comprehensive details of distinctive features required for compres- 
sion tests of porous $\mathrm{Al}$ and $\mathrm{Al}$ foams was done on the base of newly developed Standard ISO. Special attention was paid for determination of key mechanical parameters. Among them, (i) quasi-elastic structural stiffness $m$ as equivalent of Young's modulus for dense materials, (ii) compressive offset yield stress, (iii) plateau stress that is strongly dependent on processing route and, hence, on ductility and damage behaviour of the cell wall materials were designated as those the most important for engineering design.

Successful application of harmonized recommendations was demonstrated for determination of key mechanical parameters of several kinds of closed-cell $\mathrm{Al}$ foams, all fabricated via melt processing like $\mathrm{Al}$ pores route in which either titanium hydride $\mathrm{TiH}_{2}$ or calcium carbonate $\mathrm{CaCO}_{3}$ were employed as foaming agents. Significant effect of processing additives on micromechanism of deformation and, in turn, on macroscopic compressive response of $\mathrm{Al}$ foams resulted from contamination of the cell wall material by side products has been shown and clarified.

\section{REFERENCES}

1. M. F. Ashby, A. G. Evans, N. A. Fleck, L. J. Gibson, J. W. Hutchinson, and H. N. G Wadley, Metal Foams: A Design Guide (Boston: Butterworth Heinemann: 2000).

2. J. Banhart, Prog. Mater. Sci., 46, No. 6: 559 (2001).

3. L. J. Gibson and M. F. Ashby, Cellular Solids: Structure and Properties (Cambridge: Cambridge University Press: 1997).

4. V. Crupi, G. Epasto, and E. Guglielmino, Metals, 1, No. 1: 98 (2011).

5. J. Banhart, Adv. Eng. Mater., 15, No. 3: 82 (2013).

6. T. Nakamura, S. V. Gnyloskurenko, K. Sakamoto, A. V. Byakova, and R. Ishikava, Mater. Trans., 43, No. 5: 1191 (2002).

7. S. V. Gnyloskurenko, T. Nakamura, A. V. Byakova, Y. N. Podrezov, R. Ishikawa, and M. Maeda, Can. Metall. Q, 44, No. 1: 7 (2005).

8. O. V. Byakova, A. A. Vlasov, S. V. Gnyloskurenko, and I. Kartuzov, Sposib Oderzhannya Spinenykh Zlyvkiv z Alyuminiyu ta Alyuminiyevykh Splaviv (Method for Making the Blocks of Foamed Aluminium/Aluminium Alloys): Patent 104367UA. MKI, C22C 1/08, 21/00 (Publ. 27. 01. 14, Bul. No. 2) (2014) (in Ukrainian).

9. L. J. Gibson, Ann. Rev. Mater. Sci., 30: 191 (2000).

10. D. Kritz, B. Foroughi, R. Faure, and H. P. Degisher, Mater. Sci. Technol., 16, Nos. 7-8: 792 (2000).

11. A. E. Markaki and T. W. Clyne, Acta Mater., 49, No. 9: 1677 (2001).

12. A. Byakova, S. Gnyloskurenko, A. Sirko, Y. Milman, and T. Nakamura, Mater. Trans., 47, No. 9: 2131 (2006).

13. A. V. Byakova, S. V. Gnyloskurenko, and T. Nakamura, Metals, 2, No. 2: 95 (2012).

14. A. Byakova, I. Kartuzov, S. Gnyloskurenko, and T. Nakamura, Adv. Mater. Sci. Eng., 2014: 9 (2014). 
15. U. Ramamurty and A. Paul, Acta Mater., 52, 4:869 (2004).

16. R. Pippan, C. Motz, B. Kriszt, B. Zettl, H. Mayer, S. Stanzl-Tschegg, F. Simancik, and J. Kovacik, Handbook of Cellular Metals: Production, Processing, Applications (Eds. H.-P. Degischer and B. Kriszt) (Weinheim, Germany: Wiley VCH: 2002), p. 179.

17. U. Martin, U. Mosler, D. Lehmhus, A. Müler, and G. Heinzel, Proc. of Porous Metals and Metal Foaming Technology MetFoam-2005 (Sept.21-23, 2005) (Kyoto: JIM: 2006), p. 495.

18. Y. Sugimura, J. Meyer, M. Y. He, H. Bart-Smith, J. Grenstedt, and A. G. Evans, Acta Mater., 45, No. 12: 5245 (1997).

19. A. E. Simone and L. J. Gibsons, Acta Mater., 46, No. 11: 3929 (1998).

20. H. Harders, K. Huper, and J. Rösler, Acta Mater., 53, No. 5: 1335 (2005).

21. I. Jeon and T. Asahina, Acta Mater., 53, No. 12: 3415 (2005).

22. H. Toda, N. Kuroda, T. Ohgaki, M. Kobayashi, T. Akahori, M. Niinomi, T. Kobayashi, K. Uesugi, K. Makii, and Y. Aruga, Proc. of Porous Metals and Metal Foaming Technology MetFoam-2005 (Sept. 21-23, 2005) (Kyoto: JIM: 2006), p. 409.

23. T. Mukai, H. Kanahashi, T. Miyoshi, M. Mabuchi, T. G. Nieh, and K. Higashi, Scr. Mater., 40, No. 8: 921 (1999).

24. A. Paul and U. Ramamurty, Mater. Sci.Eng. A, 281, Nos. 1-2: 1 (2000).

25. K. A. Dannemann and J. Lankford Jr., Mater. Sci. Eng. A, 293, Nos. 1-2: 157 (2000).

26. U. Krupp, J. Aegerter, A. Ohrndorf, T. Guillen, A. Danninger, T. Hipke, J. Hohlfeld, and M. Reinfried, Proc. of Porous Metals and Metallic Foams MetFoam-2007 (Sept.5-7, 2007) (Montreal: DEStech Publications, Inc.: 2007), p. 407. 